\title{
THE GENDER-BASED VIOLENCE AS AN INSTRUMENT OF WARFARE IN ARMED CONFLICTS
}

\author{
Collins G. Adeyanju \\ Centre for Empirical Research in Economics and Behavioral Sciences, \\ University of Erfurt, Germany \\ ORCID iD: https://orcid.org/0000-0002-5398-0183 \\ gbadebo.adeyanju@uni-erfurt.de
}

\begin{abstract}
The gender-based violence in recent times has become an integral part of the on-going Boko Haram Insurgency in North-East Nigeria. Since the full-scale declaration of combat between the Nigerian state and the insurgent group, the asymmetrical tactics of the group have been evolving, based on its capabilities. The recent spike in the targeted raid and attack on female schools, markets, and female institutions purposely for abduction and kidnapping of women and girls indicated this assertion. Due to the depletion of its fighters and loss of territories, there is a surge in mass deployment of 'women and young girls' as material instruments of warfare: fighters, suicide bombers, human shields, bargaining tools, sex slaves, informants, and so on. This article appraises the gender push-pull factors responsible, motivation behind the current behavior, and proffers some policy guidance.
\end{abstract}

Keywords: Gender-Based Violence; Boko Haram; Women; Girls Abduction; Armed Conflict; Human Shield; Sexual Abuse; Suicide Bombers

\section{INTRODUCTION}

Since 2009, Boko Haram has brought to a halt all sense of normal life in the northeast of Nigeria. The group has run a campaign of killing, maiming and very recently abduction of girls and women. Social structures and institutions such as hospitals, schools, churches, mosques, markets, historical heritages, and public services and infrastructure have been destroyed. The civilian population has been deliberately targeted and subjected to unimaginable psychological and physical torture, including denied access to life saving 
services. A recent report of Amnesty International (2015a) documented evidence of war crime and crime against humanity against the group Boko Haram's name is a local moniker derived from the group's abhorrence of Western education. Its former leader, Mohammed Yusuf believed that western education corrupts the idea of the supremacy of Allah. The sect's full name is Jama'atu Ahlis Sunna Lidda'awati wal-Jihad ('People Committed to the Propagation of the Prophet's Teachings and Jihad') founded in 2002. Boko Haram is an indigenous uprising, with a radical Islamist religious ideology. Its aim is an Islamic state governed by Sharia law in Nigeria. The group is predominantly operating in the North East of Nigeria; especially, Adamawa, Borno and Yobe states; however, it is also active in Northern Cameroon, Niger and Chad. Following the rise in the group's radicalization and violent uprising, leading to the extra-judicial execution of its leader (Mohammed Yusuf) and some 800 members in July 2009, the group became fully militarized and set on revenge path; targeting the Police, military formations, and other formal structures of government.

The group's fighters are estimated to be between 9,000 and 15,000 (Leach 2006). In March 2015, the group declared its allegiance to the Islamic State of Iraq and Syria (ISIS), putting to bed speculations of links to AL-Qaeda. Boko Haram has killed more than 17, 000 and ranked second to ISIS globally in deadliness (UNDP 2017; Amnesty International 2015b), including more than 1,500 in first quarter of 2015, in attacks occurring mainly in northeast Nigeria. Upwards of 1.5 million people have been displaced in the violence - There had been 46 bomb attacks between January 2014 and March 2015, killing at least 817 people (The Guardian 2015). The group formally gained international attention in 2011 when it bombed the United Nation's building in the country's capital, Abuja, killing 23 and injuring more than 75 staff members. On $13^{\text {th }}$ November 2013, Boko Haram was formally designated a 'Foreign Terrorist Organisation' by the United States Department of State and a ransom of $\$ 7$ million placed on its leader (Reinert and Garcon 2014). The Nigerian government officially declared a state of emergency in the three affected states in May 2013 and launched a full-scale military operation against the group in 2013; a campaign which is still ongoing.

Women and girls represent the largest population of victims since the commencement of the insurgency. Amnesty International (2015) estimated that between 2014 and early 2015, the group had killed 5,500 civilians, the majority of whom were women and children. Similarly, it estimated that Boko Haram had abducted more than 2,000 girls and women. Recently, the Nigerian military had recorded some successes against the group, prompting a change in the group's tactics (Siollun 2015). The military campaign inflicted losses on its male fighters' population and the territory it controlled has diminished, and thus gender has become pivotal in its emerging strategy, as evidenced by the rise of kidnapping of young girls and women, and the use of girls (ages 9 and 13) as suicide bombers (Woods 2015). These tactics has affirmed the assumption that, the group is fighting its last battle; therefore, using all its disposable instruments. Therefore, this article's objective is to takes a cursory look at the motives for the new tactics of operations by Boko Haram - its apparent hunt for girls and women. The new trend of using women as bait, financial operators, 
intelligence gathering and informant, sex toys, human shield, fighters, suicide bombers, transporters, new unsuspecting inductees, and so on; is alarming. The article significantly helps bring to fore the gender-based component of the conflict, which has been underresearched. It concludes that, the group's new gender-oriented tactics is motivated by some factors, and strategic policy response is required to address it.

\section{THE CONCEPT OF GENDER-BASED VIOLENCE (GBV)}

In view of the patriarchal nature of early societies, GBV are often perpetuated by men against women. Therefore, GBV is used interchangeable as Violence against Women (VAW). The 1993 UN Declaration on the Elimination of Violence against Women (VAW) offered the first official definition of the term Gender-Based Violence: "As any act of violence that results in, or is likely to result in, physical, sexual or psychological harm or suffering to women, including threats of such acts, coercion or arbitrary deprivations of liberty, whether occurring in public or in private life" (Population Reference Bureau 2001). European Institute for Gender Equality (EIGE) defines violence against women as "all acts of masculinity that promotes or is likely to result in harm or suffering to women, including threats of such acts" (EIGE n.d.).

The World Health Organization (WHO) (WHO, cited in EIGE) estimates that at least one in every five of the world's female population has been physically or sexually abused at some time. Gender based violence can be categorized into three broad dimensions: violence against women perpetuated at home/domestic, at community/society level and by the state (Jekayinfa 2003).

1. Domestic violence against women constitutes a major component of GBV and is mostly perpetuated by men. This involves physical, sexual, psychological abuse of women by male partners and non-partners. According to a 2013 global review of available data, 35 per cent of women worldwide have experienced either physical and/or sexual intimate partner violence or non-partner sexual violence; while 70 per cent have experienced physical and/or sexual violence in their lifetime from an intimate partner (UN Women 2013).

2. Violence against women is as endemic at the general community level as in families, since it is an extension of the family. Since the community is structurally skewed towards male-dominance based on gender roles, women are subjected to decisions or acts they have no influence or contribution over, especially in developing countries, such as; Female Genital Mutilation (FGM), forced/coerced birth control and abortion, and child marriages. More than 133 million girls and women have experienced some form of FGM in the 29 countries in Africa and the Middle East where the harmful practice is most common (UN Women 2013). This is violence perpetuated by community practices.

3. Violence against women inspired by the state usually reflects the ways and manners the institutions of state operates, especially, by promoting cultural, social and legal 
practices that create unequal platforms/opportunities or freedom for both men and women. Religious and traditional fundamentalists have used this medium to exclude women's rights to economic autonomy and choices, and consequently various forms of abuse.

\section{GENDER-BASED VIOLENCE IN NIGERIA}

In Nigeria, GBV differs in regional prevalence, besides the new Boko Haram interest in women. Violence against women in Nigeria has similar dimension and forms just as in most developing countries. Available scanty data shows religion and ethnicity, as the main drivers of physical and sexual abuse affecting as many as 35.1\% of Igbo women (South-East Nigeria) and 34.3\% of Hausa-Fulani women (Northern Nigeria) (Oladepo and Arulogun 2011). FGM, forced/child marriage and widowhood practices, hair-shaving and restriction to the homes are rights issues/abuses that remain a socially subjective discuss in Nigeria. Also, some sections of the Nigerian laws aid and abate GBV, especially, the right to assault of a wife in Section 55 of the penal code: secondly, in Section 6 of the criminal code, lack of legal recognition for partner or non-partner rape technically leaves women constantly vulnerable (Ifemeje 2012). The essence of an appraisal of GBV in this section is to provide an overview on the existing social state of violence against women and consequently how Boko Haram had capitalized on it to build a new conflict strategy in the on-going insurgency in Nigeria. It is argued that, women and girl are now officially a weapon of warfare, and an increasingly significant component of Boko Haram's tactics.

\section{THEORETICAL ARGUMENT: STRUCTURAL FUNCTIONALISM}

It is adopted to explain gender relations and conflicts. The author Pope postulated that society exists for reasons and the reasons are positive; so, all must be done by all to preserve that purpose for the benefit of the society (Pope and Parsons 1975). The theory argues that societies are maintained or stabilized by harmonious relationship between individuals for the good of all members, with exception to sudden undesirable change. Changes that are good are considered positive in order to maintain the society, while bad change or demands are resisted so as to prevent disorientation or disarticulation of the existing societal order. The theory explains how individuals, groups and societies in general perceive the role of gender and its bias for preservation of status quo. That since the society is socially constructed to operate in certain ways/social functions; this should be adhered to without change (Kingsbury and Scanzoni 1993). It argues that, since a social pattern of behavior is already created for a society to operate (like bureaucracy); it is efficient to stick it. In gender relation, it is typically argued until recently, that the traditional gender roles in families should be sustained - man provides for the family, while the woman manages the home (care for kids and home chores); therefore, influencing the power relationship in favor

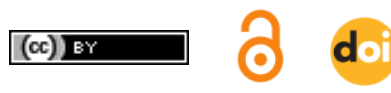


of the man. This is essentially visible because in the traditional African societies, money and wealth defines power and in turns engender success. Cultural or social revolution is not permissible within this framework, resulting in coercion of women into submission for survival.

Structural functionalism argues that, since this is the method societies had operated, it is the best way to organize it. Boko Haram is an extrapolation from a society which perceives the role of women in the above context. Therefore, western education in itself is a sin and offensive enough to their own doctrine of Islam, much less so education of girl children; as the case in North-East Nigeria. The subjugation in gender roles created by the existing order/status quo provided the platform for women to be objectified and used to prosecute armed conflict by Boko Haram.

\section{WOMEN AS A TOOL IN BOKO HARAM OPERATIONS}

The concept of gender-based violence, especially against women is taking a proportional dimension following the rise in Boko Haram conflict. Since the commencement of full-scale armed conflict against the Nigerian state, Boko Haram had constantly evolved its strategies of operations. Hitherto, the strategies that it had used were mainly attacks on public infrastructures such as communication facilities, electricity distribution sources, government buildings, schools, police stations, hospitals, or markets; as well as coordinated attack on security forces at strategic locations within formations or military check points and barracks or bases; targeted assassinations of political and religious individuals who do not share their ideological views; and kidnappings or abduction for ransom.

The group introduced a new dimension into its mode of operation (Watt 2015). That is, the deliberate hunt for women and girls, most famously being the abduction of the Chibok Girls from the small town of Chibok in Borno State. This act has elicited reactions globally. On the $14^{\text {th }}$ April 2014, the group invaded a Government Secondary School in Chibok, Borno State, camouflaged in military uniform, and abducted 276 girls, aged between 11 and 18, out of which 57 escaped (Watt 2015). Less than two month later, in the midst of calls and clamors both locally and internationally for the release of the girls, the insurgents abducted 63 more women from Kummabza in Borno State (Haruna 2014).

Since then, more abduction of women has taken place; as many as 2,000 according to Amnesty International. Therefore, the paper argues that the insurgent group may have changed its tactics to include female hostage taking due to a variety of reasons or factors:

\section{Bargaining Power}

In the two videos released immediately after the school-girls' abductions by the group in June and July 2014, they expressed their willingness to release the girls in exchange for its commanders, men and members of their families in custody of the Nigerian security agencies. Although the Nigerian Government initially has said it won't succumb to the 
demands of the insurgents, however, due to pressure from citizens and the international community through the '\#BringBackOurGirls' campaign, the Nigerian government worked behind the scene with both local and international negotiators to consider the offer (Olorunyomi 2014). Chadian authorities moved to mediate; the offer was later regarded as a decoy following the overrunning of the military barracks in Maiduguri. It resulted in a trustconflict between the Chadian and Nigerian government (Ewekor 2014).

The use of women as weapon of bargain is not a new concept adopted by insurgent groups or rogue states. However, since the end of WW11, the use of women as tools or weapon of warfare in the XXI century, through the various Geneva conventions and international treaties have been prohibited. Owing to the success of Nigerian and multilateral military offences and its depleting number, the group is running low on fighters. Therefore, in order to address the dwindling fortune of their frontline commanders, they resorted to the abduction of women; even little girls who are still considered children.

The sensitivity of society towards this issue had enhanced pressure on the government to negotiate with the group, thereby putting Boko Haram on a better negotiating standpoint. Prominent world leaders have lent voices to the release of these girls and for Nigerian government to do more; including David Cameron, Barack and Michelle Obama, Ban Ki Moon, and very recently Malala Yousafzai. Since the abduction of the Chibok girls, there had been tumultuous criticism from Nigerians and the international community on the snailpaced response of the government of Nigeria; which further increases the bargaining ability of the group.

Human Shield

The 'Human shield' is a military and political term describing the deliberate placement of non-combatants in or around combat targets to deter the enemy from attacking (Geneva Convention). This technique is illegal by the four Geneva Conventions (e.g. rule 97), however, rebel groups have used the strategies; a recent example was the Tamil Tiger group (LTTE) in Sri Lanka and Maute fighters in the Philippines. The human shield tactics of the sect is designed to literally keep women and girls in and around them as covers against attack from the security forces. This strategy had proved successful for the group, as the Nigerian Air Force and drones finds it difficult to attack their camps, especially in Sambisa Forest; in order to avoid innocent deaths of women and girls being used as human shield. There are fears that the insurgents could be provoked to kill the girls should the military try to free them using force. Because of the shield these girls provide to Boko Haram fortress of Sambisa Forest, so much caution and restraint had prevented the military from advancing their offences against the group into the forest, until very recently. 


\section{Indoctrination as Fighters and Unsuspecting Suicide Bombers}

The sequence of involvement of women in coordinated attacks had provided impetus to suspicion that women are being used as fighters, suicide bombers, logistic coordinators, etc. For example: In August 2013, among some Boko Haram suspects arrested was a 35-year old woman (Marama 2013). In June 2013, two women wearing veil were apprehended with an AK-47, a pistol and improvised explosive devices (IEDs) (Vanguard News 2013). Shortly after, another set of women, concealing rifles under their garments were among five arrested Boko Haram suspects (The Guardian 2013). This is similar to the Al-Qaeda's tactics, of using women to smuggle weapons and carry out suicide attach in Iraq. This was convenient because women are less likely suspects as suicide bombers and possesses the ability to starch ammunitions under their garments without suspicion at security check points (Sjoberg and Gentry 2001); especially in a conservative society. These strategies have been used in Pakistan, Israel, Indonesia, UK and importantly the liberation campaign in Algeria (Zenn and Pearson 2014).

Recent suicide bombing events, especially in Maiduguri and Damaturu, involving trained female Boko Haram members (as young as girls aged 10-14 years old) and some arrests are shooting down the widespread notion that the insurgency is strictly an all-male affair (masculinity engrained). This is a testament to the assumptions in quotas that women have become a new veritable weapon of war used by the group; however, testimonies from rescued women show they are being forced against their will like the 'black diamond' in Liberia. Women and girls are trained to fully accept Boko Haram's ideology and principles; adding to their unsuspecting attack capabilities. This was evidence in one of the videos released following the Chibok Girls abduction, showing the girls reciting verses in the Koran and dressed in Niqab (veil worn by Muslim women). Even though majority of these girls were Christians, they are now forced to accept Islam against their faith.

Similarly, in July 2014, the Nigerian Army announced that two women collaborators were caught by the Military. One of them was accused of coordinating payments on behalf of Boko Haram's operatives (Channels Television 2014). Reports also indicated details of three female Boko Haram members, who were secretly recruiting women into the female wing of the terrorist cell. They were caught on their way to Madagali town from where they were to transit to the forest to reunite with their cohorts. Shortly after, a woman, laced with explosive devices concealed inside her Hijab killed herself and a soldier close to the quarter-guard of the 301 Battalion of the Nigerian Army in Gombe (Channels Television 2014).

Between 2014 and 2015, the intensity of women being used solely as suicide bombers had sky-rocketed, compare to before 2014. This further supports this paper's argument about the new wave in girls and women as the Boko Haram group's operational tool. The terrorist group is reported to have deployed over 50 female suicide bombers to Maiduguri, Borno state, targeting to kill 100,000 people (Magdaleno 2014). In a study on the relationship between gender and violent behavior, Afghan scholar Amy Caiazza observed that "societies

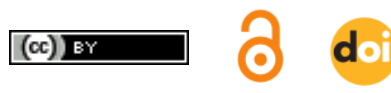


that condone and even promote violence against women have shown over and over again that they (women) tend to be violent in other ways as well" (Idris 2014).

Domestic Activities

By the teaching of Boko Haram sect, a woman's life revolves only around domestic chores and childcare. They are not to be seen in public carrying out any activity which is not given to them by Allah. They are not meant to receive any kind of education that will expose them to any activity outside their husband's home. Therefore, they should not consider any training, especially western kind of education; rather, limit their knowledge to Islamic religion and Arabic education. This is similar to Uganda Lords' Resistant Army (LRA), where female abductees are forced to cook, carry supplies and act as servants to the camp commanders (Annan et al. 2008). Boko Haram has shown the need for these women as domestic workers to take care of their environment, especially in the area of cooking.

\section{Sexual Satisfaction/Abuse}

Accounts from majority of women rescued from the group's enclave shows they are constantly assaulted and became nothing but sex slaves; raped daily. Following recent successes by the Nigerian military, by April 2015, more than 534 women have been rescued from the group; out of which 214 of them are pregnant already (Joshi 2015). Asabe Aliyu, one of them said "they turned me into a sex machine; they took turns to sleep with me. Now, I am pregnant, and I cannot identify the father" (Joshi 2015); corroborating the group's leader proclamation "we would marry them out at the age of 9, at the age of 12" (Daily Times 2015). This new behavior (abduction of women) is therefore linked to the need for sexual satisfaction. This behavior corroborates emphasis that sexual desire forms a core parameter in the women and girls' abductions adventure of the group. They abducted women and girls during raids on towns and villages and are forced to marry Boko Haram members. Sexual abuse or GBV is also used as weapon of warfare against perceived enemy-communities (communities cooperating with Nigerian state); in addition to masculinity poking on males of the communities. "What I think is going on is that they are using women and women's bodies as weapons of war and weapons of oppression and that business model is not only with Boko Haram, it's also with ISIS. They see it as a means of advancing their cause and getting the attention of the world" Dr. Babatunde Oshotimehin acknowledged (Joshi 2015 Op. cit.).

These aspects of women exploitation were once a familiar reminder of rebel movement's behavior in fragile and conflict zones of Sub-Saharan Africa. For example, civil conflicts in Mozambique, Sierra Leone and Rwanda have all witnessed various forms of gender violence, including sexual abuse and forced marriage and conscription of enemy women into insurgent groups (Turshen 2001). Similarly, in Uganda, soldiers with Joseph Kony's Lord's Resistance Army (LRA) were routinely engaged in the sale and 'transfer' of 
women (Amnesty International 1997). The risks are unimaginable, ranging from: psychological trauma, unwanted pregnancy, Sexually Transmitted Diseases (STDs), HIV-AIDS, Vesicovaginal Fistula (VVF), and so on.

\section{THE ROLE OF MASCULINITY}

The masculinity component in the conflict had been very limited or at best unreported. Boko Haram portrays the notion that combats are for the male, while women are expected to be home-makers and serve their warrior-husbands. The Hegemonic masculinity forms strong fabric of Boko Haram ideology, due to cultural patriarchy in Nigerian society; evidence in legitimacy of male dominance in economic, social and political order. However, an iota of masculinity evidence in the group is demonstrated by the celebrations after each success over the Nigerian military; especially when the barracks/camps are overrun, and heavy artilleries captured. These armaments (e.g. armored tanks) are displaced and driven recklessly to display the masculine alpha-male ego of victory. They climb on the tanks and yell while shooting sporadically; a display similar to male domination euphoria in some cultures. On the part of the Nigerian military, female soldiers are equally not deployed in combat positions; a stand that also portrays the notion that, it is an all-male affair. 


\section{CONCLUSION}

Since 2012, abductions of women and girls have become an official Boko Haram tactic, however, reached an unprecedented level between 2014 and 2015. Apparently, the advances or successful dislodgment of the group from some territories by the security forces is causing Boko Haram to evolve tactically, thereby forcefully enlisting women. While voluntary enlistment of female fighters is plausible as seen in Liberia (the black diamond) and others, there had not been substantial evidence linking the group and voluntary association by women.

In 2014, the four countries of Niger, Cameroon, Chad and Nigeria established a coalition of military offence against the group. The successes recorded had led to loss of territories initially occupied by the group, including its caliphate headquarters - Gwoza. Moreover, the safe haven (Sambisa Forest) has been raided, even though the crimes are still continuing. It is believed that, with the transition of power to a newly elected president Muhammadu Buhari in May 2015, who had promised to end the conflict and bring back the Chibok Girls; more positive results are anticipated. If this trend becomes normal without strong reaction from the global community and the state, it could send positive signal to insurgent group across conflict zones, where women and girls have increasingly become tools for armed conflict prosecution and sustenance. This new phenomenon must be discouraged in all its ramifications. While the search for a military solution is under-way against Boko Haram, economic intervention plan must be developed to address the initial assumptions (abject poverty, neglect, social and political exclusion) surrounding the rise of dissidents in the North-East Nigeria.

In addition, an economic recovery strategy is necessary to cushion the devastation of the zone following long years of destructions. Finally, a rehabilitation framework is pertinent to reset the morals, psychology, acceptable religious ideology and social structure that sustain reintegration of the displaced population. The international development organizations, Nigerian government and donor agencies must invest in the peace-building and post-conflict infrastructure of the region. Above all, the conflict could reproduce another circle in shortest future if the local grievance and frustration that pushed idled youths towards Boko Haram violent extremism is not addressed; such as poverty, unemployment, lack of economic opportunities, and inequality.

\section{Recommendations}

- The new Nigerian government must structurally change the socio-economic injustice and tackle political corruption that creates a supply line of willing Boko Haram adherents. Since at the heart of the remote cause of the uprising was poverty, social neglect and poor governance, Nigeria's new government should develop an 
economic and political master-plan that specifically addresses youth unemployment; and minimizes the sense of detachment and alienation.

- The legal framework should be look into, especially criminalization rape

- There should be immediate release of family members of the group leaders, including their wives, unduly incarcerated by the security forces without evidence of aiding the group.

- There should be an improved regional communication, coordination and cooperation amongst countries contributing to the multilateral forces and who shares borderline with north-east Nigeria, for effective result; especially the Lake Chad Basin.

- Adequate security measures should be put in place, especially in schools and public facilities, in order to forestall future reoccurrence of Chibok experience.

- A systemic rehabilitation process should be set up in order to reintegrate released victims and internally displaced person (IDP) back into the society and normal life.

- Nigerian government should mobilize all its capabilities, including diplomacy and negotiation towards ending the conflict.

- Areas recaptured from the group must be adequately protected to prevent a rebound and revenge on the communities; and a functioning government restored. There must be considerable investment in new infrastructure and livelihood, and security; schools, hospitals and other social institutions. 


\section{REFERENCES}

1. Amnesty International Report (2015a). Index number: AFR 44/1360/2015. (Accessed 15 January 2018): https://www.amnesty.org/en/documents/afr44/1360/2015/en/

2. Amnesty International Report, (1997). Uganda, Breaking God's Commands: the Destruction of Childhood by the Lord's Resistance Army, New York.

3. Amnesty International, (2015b); P. 1.

4. Annan et al, (2008): The State of Female Youth in Northern Uganda: Findings from the Survey of War-Affected Youth (Sway); Phase II. (Accessed on 26 Dec. 2017): www.swayuganda.org

5. Channels Television (2014, Nov. 2). Nigerian Army Arrests Boko Haram Accomplice Informant, (Accessed 22 December 2017): http://www.channelstv.com/2014/07/02/nigerian-army-arrests-boko-haramaccomplice-informant/

6. Daily Times Newspapers, (2015, May 4). In Sambisa, Men Took Turns to Have Me, Now I'm Pregnant. (Accessed on 5 Dec. 2017): https://dailytimes.ng/in-sambisa-men-tookturns-to-have-me-now-im-pregnant/

7. European Institute for Gender Equality (EIGE) (n.d.): Gender Based Violence. (Accessed 9 September 2017): http://eige.europa.eu/content/activities/gender-basedviolence\# ftnref2

8. Ewekor, Chris (2014, Oct. 17): Nigeria and Boko Haram 'agree ceasefire and girls' release. BBC News.

9. Haruna, A. (2014, June 24). Another 60 Women Abducted in Borno Leadership Newspaper. (Accessed 18 October 2017): http://leadership.ng/news/375653/another60-women-abducted-borno

10. Idris, Hamza. (2014, July 12). Behold the Women of Boko Haram. Daily Trust Newspapers, Maiduguri, (Accessed 1 December 2017): http://dailytrust.com.ng/weekly/index.php/top-stories/17031-behold-the-women-ofboko-haram.

11. Ifemeje, S.C. (2012). Gender-Based Domestic Violence in Nigeria: A Socio-Legal Perspective. Indian Journal of Gender Studies: Vol. 19, No.1, Pp. 137-148.

12. Jekayinfa, A.A. (2003). Types, causes and Effects of Gender Based Violence challenges for Social Studies Education in Nigeria: Gender Discourse 1(1).

13. Joshi, Priya. (2015, May 8). Boko Haram in Nigeria: Women Describe being 'Sex Machines' for Islamist Captors. International business Times (IBT): (Accessed 29 January 2018): https://www.ibtimes.co.uk/boko-haram-nigeria-women-describebeing-sex-machines-by-islamist-captors-1500247

14. Kingsbury N. and Scanzoni J. (1993). Structural-Functionalism - in Sourcebook of Family Theories and Methods: A Contextual Approach. Plenum Press, New York, Chapter 9, pp. 195-221. 
15. Leach, J.D. (2016). Boko Haram: Diverging Approaches to Fighting Insurgency. Journal of Politics and Democratization, Vol. 1-2, P. 1.

16. Magdaleno, J. (2014, Dec. 5). Boko Haram Plans to Massacre 100,000 Nigerians with Female Suicide Bombers. VICE News Reports.

17. Marama, Ndahi. (2013, Aug. 17). JTF, Vigilante Arrests Female Boko Haram Suspects; Vanguard Newspapers, Maiduguri. (Accessed 15 February 2018): https://www.vanguardngr.com/2013/08/jtf-vigilante-arrest-female-boko-haramsuspects/

18. Oladepo, Y. and Arulogun O.S. (2011). Factors Influencing Gender Based Violence among Men and Women in Selected States in Nigeria, African Journal of Reproductive Health, December 15(4): 78-86.

19. Olorunyomi, Dapo. (2014, Sept. 25). How Nigerian Government Bungled Edwin Clarkled Fresh Negotiation to Free Chibok Girls. Premium Times.

20. Parsons, Talcott. (1975). The Present Status of Structural-Functional Theory in Sociology; In Parsons, Talcott: Social Systems and the Evolution of Action Theory, the Free Press, New York.

21. Pope, W. (1975). Durkheim as a Functionalist: The Sociological Quarterly, 16(3), 361379. (Accessed 12 December 2017): http://www.jstor.org/stable/4105747

22. Population Reference Bureau (2001), Measure Communication.

23. Reinert, M and Garcon, L. (2014). Boko Haram: A Chronology. In Marc - Antoine Perouse de Montclos (eds): Boko Haram Islamism, Politics, Security and the State in Nigeria; African Studies Centre, Pp. 245.

24. Siollun, Max (2015, May). How Nigeria Turned a Corner against Boko Haram. The Guardian.

25. Sjoberg, L. and Gentry, C. (2001). Introduction. In Sjoberg, L. \& Gentry, C. (eds.): Women, Gender and Terrorism. University of Georgia, Georgia.

26. The Guardian (2013, August). JTF, vigilance Group Capture Five Suspected Terrorists: Featured in Beegeagle Blog. (Accessed 5 September 2018): https://beegeagle.wordpress.com/2013/08/13/jstf-troops-vigilance-group-capture-5suspected-terrorists-in-borno-including-2-women-with-rifles-hidden-underneaththeir-hijabs/

27. The Guardian (2015). Nigerian Army Frees Hundreds more Women and Girls from Boko Haram. May 2, 2015. (Accessed on 5 Dec., 2017): http://www.theguardian.com/world/2015/may/02/nigerian-women-girls-boko-haramrebel

28. Turshen, Meredeth. (2001). The Political Economy of Rape: An Analysis of Systematic Rape and Sexual Abuse of Women during Armed Conflict in Africa. In Moser C. \& Clarke F. (eds): Victors, Perpetrators or Actors: Gender, Armed Conflict and Political Violence. Zed Books, London: Pp. 55-68. 
29. United Nations Development Programme (UNDP) Report (2017). Journey to Extremism in Africa: Drivers, Incentives and the Tipping Point for Recruitment. (Accessed 27 December 2017): http://journey-to-extremism.undp.org

30. United Nations Women (UNW) Report, (2013). Facts and Figures: Ending Violence against Women, a Pandemic in Diverse Forms. (Accessed on 27 Dec., 2017): http://www.unwomen.org/en/what-we-do/ending-violence-against-women/factsand-figures\#sthash.xCTUGDQK.dpuf

31. Vanguard News, (2013, June 30). Vigilante Arrests Two Women with Assault Rifle, IEDs in Maiduguri. (Accessed 28 December 2017):

https://www.vanguardngr.com/2013/06/vigilante-arrests-2-women-with-assaultweapons-ied-in-maiduguri/

32. Watt, Ewan. (2015, May 27). Shocking Increase in Use of Child Suicide Bombers by Boko Haram: Theirworld. (Accessed on 29 Dec., 2017): http://theirworld.org/news/shockingincrease-in-use-of-child-suicide-bombers-by-boko-haram

33. Woods, M (2015). Boko Haram could be Using Kidnapped Chibok Schoolgirls as Suicide Bombers.Christian Today. 2015, May 26.

34. World Health Organization (WHO) Report cited in EIGE

35. Zenn, J. and Pearson, E. (2014). Women, Gender and the Evolving Tactics of Boko Haram: Centre for the Study of Terrorism and Political Violence, Journal of Terrorism Research; Volume 5, Issue 1. 